\title{
Pluralism and Freedom of Religion in Indonesia In Context of the Religious Blasphemy Prevention Act
}

\author{
Johannes Johny Koynja \\ Lecturer and Researchers in the Constitutional Law Department \\ Faculty of Law Mataram University \\ Email: johnykoynja@gmail.com
}

\begin{abstract}
The point of the problem spectrum that becomes the legal issue in this article is in the establishment of the Act Number 1/PNPS/1965 on Prevention of Abuse and/or Blasphemy to the Religion as requested its examination to the Constitutional Court. The Constitutional Court of the Republic of Indonesia in its decision assess that the Applicant, in fact, wishes only to look for interpretation and form "freedom of religion and confidence" in Indonesia. For that, the legal analysis was done to the problem of pluralism of religion in Indonesia it's bearing on the implementation of the Religious Blasphemy Prevention Act, ideally, include three analysis, that is governance science (bestuurkundige), human rights, and freedom of religion values analysis of requested its examination to the Constitutional Court. Discussion concerning relations among religion and state become to draw to be studied by its bearing about how the ought relationship of religion and state in Indonesia society embracing pluralism. The freedom of religion and confidence, in fact, do not represent absolute matter the religious believers to free and ease, but Also have to at one's feet of demarcation the religious believers there are in Article 28J of the sentence (2) The 1945 Constitution of the Republic of Indonesia as the supreme law of the which represent Staatsfundamentalnorm roommates giving guidance of freedom of religion and confidence in Indonesia. In the context needed or it's not the Religious Blasphemy Prevention Act, allimportant only how State or Government able give the guarantee that law and regulation the which published can become base management of conflict between society the which is plural wisely and can become socio-cultural supporter national tighten tying, arrange the democratic system and governance, so that various distortion potency flange at the happenings of interfaith conflict, internal conflict and external Also can lessen, not simply forming and equipping peripherals of law and regulation.
\end{abstract}

Keywords: Pluralism, Freedom of Religion and Confidence, the Religious Blasphemy Prevention Act 


\section{INTRODUCTION}

Religious pluralism is a social reality that can not be eliminated in a universal society. In fact, any attempt to eliminate any pretext, including efforts to eliminate jargon for the sake of unity, it will cause unrest, social upheaval, civil unrest and social disintegration ${ }^{1}$. Because unity is precisely to be achieved through the existence of plurality.

Regarding the religious life, it can be said that all the major world religions in Indonesia, even including Judaism ${ }^{2}$. Besides, there is also a wide range of "religions" are in traditional tribal ${ }^{3}$, including schools or organizations psychotherapy / public confidence ${ }^{4}$, That is, some scholars call and characterizes the people of Indonesia as a "dualistic" ${ }^{5}$, "Paradoxical" ${ }^{6}$, and "antagonistic"7 as well as other titles similar.

It must be admitted that the empirical reality that occurred in Indonesia has put unity (unum) as a concept that is impossible to be realized through the sacrifice of his plurality, because the people of Indonesia who adopts pluralism

1 "SARA Framed Pluralism", Heru Nugroho, Kompas, Saturday, March 15, 1997, p.5

2 Based on the 2000 national census, there are a small number of Jewish communities who live in Jakarta and Surabaya.

3 Gavin W.Jones. (1978). Religions in Indonesia: History and Development. Jakarta: Prisma, p. 215-219

4 Based on reports of Ministry of Religious Affairs (MoRA), which reported that in 1953 there were more than 360 Faith groups in Java. Schools or organizations psychotherapy / public trust is considered to be contrary to religious values. This situation is considered likely to result in violations of the law, breaking the national unity, abuse and / or use of religion and tarnishing religion. The development flow and psychotherapy organizations considered to have evolved to jeopardize the existing religions. These groups play a decisive role until the 1955 elections, in which Islamist parties won a lot of failures in the majority.

5 JH Boeke, (1953), Economics and Economic Policy of Dual Societies as Exemplified by Indonesia, Harleem: HD Tjeenk Willink, p.14.

6 Jeanne S. Mintz. (1953). Mohammed, Marx and Marhaen, New York, Washington, London: Frederick A.Praeger, p. 25.

7 Reuven Kahane. (1973). The Problem of Political Legitimacy in an antagonistic Society: The Indonesian Case, Sage Research Papers in the Social Sciences, Vol 1, Series No. 90-005, Studied in Comparative Modernization Series, Beverly Hills and London: Sage Publications, p.72. 
tend potential to cause tension or conflict permanent of various strengths dialectic contained the plurality of religion itself.

The problem becomes more interesting, because the point spectrum into the legal issues in this article, the problems lie in the establishment of the Act Number 1/ PNPS / 1965 on the Prevention of Abuse and / or Blasphemy ${ }^{8}$ petitioned to the Constitutional Court ${ }^{9}$. The principal petition of the Petitioners is the examine the constitutionality of Article 1, Article 2 paragraph (1), Article 2 (2), Article 3, Article 4 paragraph a of the Act Number 1/ PNPS / 1965 on the Prevention of Abuse and / or Blasphemy by finding the form or formula of justice constitutional interpretation "religious freedom" in Indonesia through the interpretation of the Court.

Constitutional Court ruling rejected the request for a judicial review of Law Prevention of blasphemy, have shown that the Constitutional Court attempted to establish the level of legal certainty evident that almost always moved from three factors, namely: First, from the rules of the law itself; Second, of the agencies that make up and apply the law, which together with the legal form a legal system; Third, from the broader social environment: political factors, economic and sociocultural. To that end, the legal analysis conducted on the issue of pluralism and religious freedom in Indonesia related to the implementation of the Religious Blasphemy Prevention Act, ideally includes three layers of analysis, namely: the juridical (the science of government (bestuurkundige), human rights, and analysis the values of religious freedom.

8 The Act Number 1 / PNPS / 1965 hereinafter referred to the Religious Blasphemy Prevention Act, in initially shaped the Presidential Decision (Penpres) Number 1 of 1965 issued by President Ir.Soekarno on January 27, 1965. The Presidential Decision is actually a part of NASAKOM idea is to mobilize the forces of nationalism, religion and communism in order to increase its political strength.

9 A petition against Article $1 \mathrm{~s} / \mathrm{d} 4$ of the Act Prevention of blasphemy which the Petitioner considered contrary to the 1945 Constitution (unconstitutional).

10 The petition for judicial review of the Religious Blasphemy Prevention Act is proposed by four individuals, namely: KH Abdurahman Wahid (late), Siti Musdah Mulia, Dawam Rahardjo, and Maman Imanul Haq; and seven civil society organizations, namely: Indo Legal Aid FoundationEng (YLBHI), Impartial, Equivalent Institute, Demos, Elsam, Desantara, and the Indonesian Legal Aid Association (PBHI). 
Further, although in the end the judicial review request the Religious Blasphemy Prevention Act against the 1945 Constitution, by the Constitutional Court declared unacceptable (niet ontvankelijk verklaard) and decided to reject the entire Petitioner's petition ${ }^{10}$, but the discourse on the relationship between state and religion be interesting to examine closely as to how should the relation between religion and the state in a society that embraces pluralism such as Indonesia. So that's it, care should be taken to address issues of religious freedom and religious defamation under the Act Prevention of blasphemy, as the issue "very sensitive" in a constitutional perspective.

There are two questions related to the rejection of urgency ${ }^{11}$ petition for a judicial review of The Act Number 1 / PNPS / 1965 on Prevention of Abuse and / or blasphemy against the 1945 Constitution. First, where were the constitutionalities of the Religious Blasphemy Prevention Act so that to be the basic consideration of the need for it's the Act to remain applied in a pluralistic Indonesian society? Second, why the concept of religious freedom and belief in Indonesia which is a universal concept, becomes a paradoxical concept?

\section{DISCUSSION}

\section{Constitutionality of the Religious Blasphemy Prevention Act}

It is interesting that on the one hand, the establishment Prevention Act blasphemy strongly associated with socio-political context during the reign of the Old Order apply Guided Democracy authoritarian, centralized and concentrated in the hands of President Sukarno. So few people have mentioned that the products produced at the time the law was "also are" authoritarian and centralized, not least Prevention Act blasphemy.

11 After a three-month marathon trial, the Constitutional Court ruled against rejecting the entire petition for judicial review of the five norms contained in Articles 1 to Article 4 of the Prevention of Blasphemy Act to be judicially reviewed by nine norms in the 1945 Constitution. 
The Act of Prevention Religious Blasphemy that was originally shaped The Presidential Decision (Penpres) Number 1 of $1965^{12}$ born from the situation Indonesian socio-political dynamics of competition between ideology-tinged big idologi such as nationalism, religion and communism. Furthermore, it is part of the idea of NASAKOM President Soekarno to mobilize the forces of nationalism, religion and communism in order to increase its political strength.

When assessed based on the opinions Mahfud MD of assessment indicators, whether a responsive or conservative legal products. Then Religious Blasphemy Prevention Act when viewed from the formation process can be classified into legal products with character orthodox, conservative / elitist and centralized, in the sense that more dominated by state institutions, especially the holder of executive power ${ }^{13}$.

Religious Blasphemy Prevention Act that is orthodox, tend to be positivistinstrumentalist, meaning more reflecting the social and political vision of the power-holders or contain more material as a tool for realizing the will and interests of the Government's program, while providing a wide opportunity to the

12 The Religious Blasphemy Prevention Act originally shaped The Presidential Decision (Penpres) Number 1 of 1965 issued on January 27, 1965 Sukarno.

13 Mahfud MD, (1998), Politics of Law in Indonesia, Jakarta: LP3ES, p. 26

14 Ibid.

15 In the letter the President to the Chairman of the House of Representatives (DPR) at that time, stated that in addition to the three state regulations that are expressly written in 1945, namely: the Act, Government Regulation in Lieu of Act (Perpu), and Government Regulation (PP), also stipulates the existence of several other state regulations, namely The Presidential Decision (Penpres) to implement the Decree of the President / Supreme Commander of the Armed Forces of July 5, 1959 on the "Back to the 1945 Constitution".

16 State Gazette of the Republic of Indonesia Year 1965 Number 3, Supplement to State Gazette of the Republic of Indonesia Number 2726) juncto the Act Number 5 of 1969 on Statement of Various Presidential Decision and Presidential Regulation as the Act (State Gazette of 1969 Number 36, Supplement to State Gazette of the Republic Indonesia Number 2900).

17 It should be pointed out that after Ir.Soekarno fell from the presidency, the Provisional People's Consultative Assembly (MPRS) at that time ordered the judicial review of the state legislative products outside the MPRS products that were inconsistent with the 1945 Constitution. For this purpose, was formed the Act Number 5 of 1969. Based on the Act Number 5 of 1969, then the Presiden Determinations (Penpres) Number 1 of 1965 on Prevention of Abuse and/or Blasphemy to the Religion is stipulated as the Act, which is then referred to as the Act Number 1 / PNPS / 1965 on Prevention of Abuse and / or stain to the Religion. 
Government to make various interpretations by various regulations advanced by visions unilaterally by the Government and not just simply a matter technical ${ }^{14}$.

According to the Author, although the Constitutional Court considered that the fact the establishment of the Presidential Decision (Penpres) Number 1 of 1965 become The Act Number 1 / PNPS / 1965 on Prevention of Abuse and / or Blasphemy to the Religion, have proved that the norms contained in the Act are still considered relevant in a "different context" (quotes from the Author), but the Court did not explicitly explained in the decision, either express or implied related to that purpose, making the norms contained in Religious Blasphemy Prevention Act is indeed worthy to be maintained.

By juridical, Article I of the Transitional Provisions of the 1945 Constitution after the amendment, can be used as the legal basis for enactment of Religious Blasphemy Prevention Act. Transitional Provisions confirmed that confirms that "All legislations are there still remain valid for the new has not been held under this Constitution". Because materially Religious Blasphemy Prevention Act is still required as a general prevention and controlling public order within the framework of religious harmony.

Below is the author criticizing some of the legal considerations from Decision of the Constitutional Court related constitutionality Religious Blasphemy Prevention Act, namely as follows:

1. In its decision, the Constitutional Court held that in essence, Religious Blasphemy Prevention Act, only regulate abuse and blasphemy, not to impede religious freedom in Indonesia. According to the Authors, the terminology "desecration of religion" which should be a central point in the Religious Blasphemy Prevention Act, it is not stated explicitly by the Judge of the Constitutional Court.

So that the substance of the decision by Author remains a condition that indicates an empty norm (leemten van normen), in addition to the absence of juridical consistency assertive. From the level of legal theory, 
the problem according to the Author may result in the necessity of the creation or adoption of foreign legal principles in the revision of the Religious Blasphemy Prevention Act.

This paper intends to put the existing problems in the context of pluralism and religious freedom of relevance to the Religious Blasphemy Prevention Act on the proportion in order to enforce the consistency of legal provisions normatively of the Indonesian national legal system for the improvement of the logical degree of optimal normative.

So for that, the need for redefinition ${ }^{15}$ ideal conceptions of "desecration of religion" so it is expected in accordance with the spirit of the 1945 Constitution after the Amendment as well as developments that occur to build Indonesia's future. The concept of "religious desecration" according to the Author is different from the term "religious humiliation" which tends to be directed to actions by a member or group of a particular religion against another. So, "religious desecration" in fact is an internal matter of the people of the religion concerned.

For that, the problem of religious desecration must of course be solved by the religious people concerned by using the values, rules, or rules imposed by that religion. Therefore according to the Author, the other party has no right or authority to interfere with the internal problems of religious teachings and practice of a people of a particular religion.

2. According to the Constitutional Court Judge, in essence Religious Blasphemy Prevention Act does not prohibit someone to do the interpretation of a religious teaching or conducting religious activities which resembles a religion embraced in Indonesia independently.

If any "deviant interpretation" is regarded as religious freedom because it is associated with the freedom to believe in trust, expressing

15 Redefinition means reformulation - See: Anton M.Moeliono, (1993), Dictionary of Indonesian Language, Ministry of Education and Culture, IVrd printed Jakarta: Balai Pustaka, p.191 
thoughts and attitudes according to his conscience ${ }^{16}$, then it must be seen from two sides, that is:

a. Freedom to believe.

Although the interpretation of religious teachings belief is part of freedom that is at forum internum, but that interpretation should be in conformity with the principal teachings of the true religion through a methodology based on the source of religious teachings are concerned that the Scriptures of each, so that the freedom of interpretation of a religion is not absolute or absolute.

Interpretation is not based on a common methodology recognized by religious believers and not based on Scripture relevant sources feared will lead to reactions that threaten the security and public order when presented or performed in public.

b. Freedom expresses thoughts and attitudes according to his conscience

It is true that religion ${ }^{17}$ is something personal, something very personal. However, the Republic of Indonesia based on Pancasila, the state including the Government "can be involved" in the organization of the religious life of its citizens. Especially when it appears the interpretation and/or religious activities that deviate from the principal teachings of religion are therefore not only undermine religious values espoused in Indonesia because they

16 Article 28E (2) of the 1945 Constitution clearly states that "Everyone has the right to freedom of belief believing, express thoughts and attitudes, according to his conscience".

17 According to the Author, the definition of religion itself actually has never been agreed. In the discourse of Western thought, polemics and debates about the definition of religion hardly meet an agreement, both in the field of philosophy of religion, theology, sociology, anthropology and in the field of comparative religion. No wonder if Wilfred Cantwel Smith, an expert in Religion Comparative Science, must acknowledge how difficult it is to define religion. Smith revealed extraordinarily difficult religious terminology defined (The term is notoriously indefinable). But the Author tries to give a definition of religion according to the Encyclopedia of Philosophy: trust in God who is always alive, namely the soul and the divine will that govern the universe and have a moral relationship with mankind. While the definition of religion according to the Oxford English Dictionary is "(1) the belief in and worship of a superhuman controlling power, especially personal God or Gods (2) a particular system of faith and worship (3) a pursuit or interest Followed with devition". 
conflict with the principal teachings of religion, but also resulted in the emergence of disorders of security and public order. Irregularities that can disturb and disrupt security and public order that threaten human rights.

3. Freedom of religion is actually is not an absolute thing that freely, but must also be subject to the restrictions contained in Article 28J Paragraph (2) of the 1945 Constitution ${ }^{18}$ as the Supreme Law of the land which is Staatsfundamentalnorm that provides guidelines for religious freedom.

The Author adds, that Lukman Hakim Saifuddin and Patrialis Akbar, as a Former Member of the Ad Hoc Committee I Working Body of People's Consultative Assembly (MPR), in Court at the Constitutional Court once told chronologically the inclusion of 10 new chapters which regulates Human Rights in the Second Amendment to the 1945 Constitution. According to them, the provisions of the Human Rights matter of Article 28A to 28I of the 1945 Constitution has been restricted or "locked" by Article $28 \mathrm{~J}^{19}$ of the 1945 Constitution.

4. Arrangements in the Religious Blasphemy Prevention Act is a form of state protection to ensure harmony and religious tolerance in realizing public order for the people of Indonesia, so it is still very necessary and important to be maintained as substantially still relevant, even though formally need to be repaired.

The author adds that there are currently about 20 million Javanese, Kalimantan, Papua and other regions that practice animism ${ }^{20}$ and other

22 Article 28J Paragraph (2) 1945: "In carrying out their rights and freedoms, each person shall be subject to the restrictions established by Act (bold letters from the Author) with the sole purpose of securing due recognition and respect for the rights and freedoms of others to meet the fair demands in accordance with considerations of morality, religious values, security and public order in a democratic society".

${ }^{19}$ Historically, the formulation of Article 28J of the 1945 Constitution espoused motivated by the conviction that Human Rights are not unlimited rights, Human Rights are not absolute. Therefore, based on a systematic interpretation, Human Rights set out in Article 28A to 28I of the The 1945 Constitution is subject to the restrictions provided for in Article 28J of the 1945 Constitution which is the only provision governing rights obligations.

${ }^{20}$ Animism is the belief in the power of a personal existence in this world or the things or objects. Something that is the subject, so he can do something with the willingness and ability alone. In religion, this figure was appointed to the Divine, God or gods or other spirits. In the tribal 
types of traditional belief systems are referred to as "Beliefs". In this case, the Government permits the practice of the traditional belief system "Beliefs" is simply a cultural manifestation, not as a religion. So that's it, the followers of Beliefs required to apply to the Ministry of Culture and Tourism. Although later, some animists "merge" their beliefs with one of the government-recognized religions and thus registered as a recognized religion.

5. Religious Blasphemy Prevention Act ensure that religious freedom in Indonesia is not misused to blaspheme between adherents of one religion and another which could potentially cause anarchy. Given the freedom of religion is one of the human rights of the most basic and fundamental to every human being. Commenting on the decision of the Constitutional Court, the Author subscribes to the theory of conflict, that a more appropriate community characterized by conflict rather than harmony seen. According Vold, that in a society there are various interest groups, so there will always be a conflict of interest ${ }^{21}$.

The Author adds to the start of an internal conflict in religion, for example in Islam ${ }^{22}$ in Indonesia there are streams like Nahdatul Ulama, Muhammadiyah, and Ahmadis, or abroad Shia and Sunni streams that have a different interpretation of the Qur'an ${ }^{23}$, Similarly in Buddhism ${ }^{24}$ in

religions generally, something spirited is usually designated for animals (misalnyanya snakes, birds, buffalo and crocodiles), or objects that can move and do something (eg, mountains, trees, water, fire, wind, lightning and rain), Beings or objects is believed to have a soul and they will therefore be able to do things that are good and useful, but also bad and harmful.

21 Weda Made Darma. (1996). Criminology, Jakarta: King Grafindo Persada, p.47

22 Most Muslims in Indonesia are Sunni followers, Two of the largest Islamic mass organizations, namely: Nahdlatul Ulama (NU) and Muhammadiyah, each claiming to have 40 million and 30 million Sunni followers. It is estimated that there are about 1 million to 3 million Shia followers in Indonesia.

27 Based on data from the Ministry of Religion, obtained a report that there are quite a lot of Muslim organizations on a smaller scale, including approximately 400,000 people are registered as members of a splinter group of Islam Ahmadiyya Qadiyani, There is also a smaller group again, the Lahore Ahmadiyya. Minority groups including al-Qiyadah alIslamiyah, Darul Arqam, Jamaah Salamulah, and followers of the Da'wah Islamiyah Institution of Indonesia.

28 The ethnic Chinese constitute 60 percent of Buddhists.

29 A report on the level of the International Religious Freedom reported United States Department of State (US) actually still be questionable, particularly regarding moral legality The United 
Indonesia, there is the Mahayana, followers of Theravada, adherents of the Tantrayana stream, Tridharma, Kasogatan, and Nichiren, which each have a tradition of religious rituals that differ based on the local culture, as well as several streams like Maitreya and Lu Sen Yen who have different interpretations of the subject of Buddhism.

Ending this subchapters, the Author reiterated that in the context of whether or not it is necessary Religious Blasphemy Prevention Act, the most important is how the State or Government able gave guarantees that regulations issued could be the basis of inter-community conflict management of pluralistic and capable of being the capital of socio-cultural underpinnings of national ties, governance and the democratic system, so that a variety of potential turmoil that led to the conflict between religions, both internally and externally can be eliminated, not just to form and complete the rules of legislation.

\section{Religious Freedom As The Concept of Universal Paradoxical}

According to the Author, on the other side of the state in this case the Government also needed to be alert and anticipate lest rationalism of religious freedom as a consequence of living dynamically generate atheism, because according to the Author, embryos that indicate the birth of atheism are already present in plural Indonesian society.

Religious Blasphemy Prevention Act factually it has created discrimination, as evidenced in 1952 santris a great influence in the Ministry of Religious Affairs proposes a "definition of religion" which contains the following elements, namely: Prophets, Scriptures, and international recognition ${ }^{25}$, Then in 1961, for certain political reasons, President Sukarno formally establish six religion recognized by

States government did not give an assessment to his own country, as the United States without discrimination and oppression.

25 Eka Darmaputera, (1997), Pancasila: Identity and Modernity - Review of Ethical and Cultural Rights, Molds VI, Jakarta: BPK Gunung Mulia, p.58 
the state, namely: Islam, Protestantism, Catholicism, Hinduism ${ }^{26}$, Buddhism, and Confucianism $^{27}$, Such determination is based on the definition of religion that is proposed by the Ministry of Religious Affairs, which contains four things: First, have the Scriptures; Second, Prophet; Thirdly, the principle of Almighty God, and Fourth, a legal system for its adherents.

The conditions prevailing until now, proved at the Ministry of Religious Affairs of the Republic of Indonesia (MoRA) there are only representatives of the six official religions, namely Islam, Protestantism, Catholicism, Hinduism, Buddhism, and Confucianism (Confucius) $)^{28}$, The fact that proves that the Religious Blasphemy Prevention Act have "compel" seeker group to "submit ourselves" to the religions recognized by the state.

From the standpoint of human rights, inter-religious conflicts that occurred in Indonesia according to the actual author can be judged as a false understanding of the concept of "freedom of religion". Understanding of religious freedom granted to every human being is actually not a value-free freedom and liberty as such, but freedom is accompanied by social responsibility to realize the human rights of every person.

In relation to the right to "freedom of religion", there are two aspects that need to be noticed $:^{29}$

\section{Aspects of internal freedom (forum internum)}

26 Hindu groups, such as Hare Krishna and followers of the Indian spiritual leader Sai Baba also present, although in small quantities.

39 The Supreme Council for Confucian Religion in Indonesia (MATAKIN) estimates that 95 percent of Confucians are ethnic Chinese and the rest of the indigenous Javanese. Many Confucians also practiced Buddhism and Christianity.

40 Since Confucianism (Confucius) are recognized as an official religion by the government in 2006. Subsequently, on September 1, 2008, the Ministry of Education issued two decisions that certifies Confucianism to put in Religious Studies at the school. During the reporting period, the government acquire land in Taman Mini Indonesia Indah (TMII) to establish a Confucian temple.

29 Opinions differ (dissenting opinion) Constitutional Justice Maria Farida Indrati in the Decision of the Constitutional Court of the Republic of Indonesia Number 140 / PUU-VII / 2009 on Judicial Review Number 1 / PNPS / 1965 on the Prevention of Abuse and / or blasphemy against the 1945 Constitution of the State of the Republic of Indonesia, p. 316 
Internal freedom (forum internum) concerning spiritual existence that is inherent in every individual is freedom of every person to believe, think, and choose a religion or belief, the freedom to practice religion or belief in private (italics thick of the Author), so that the internal freedom is "not to intervention" by the state.

According to the Author, on one side of Religious Blasphemy Prevention Act is still very necessary and important to be maintained because it is substantially still relevant, especially in responding to a false understanding of the concept of "freedom of religion" which is feared could undermine religious values espoused in Indonesia as opposed to the principal teachings of religion and result in the disruption of security and public order.

Departing from a few small facts above, the Author would like to emphasize that the space of religious freedom in today's era of reform, the real "no better" than ever before in the era of the Old Order and New Order. Currently there are still some local religion or religious native or indigenous religions are less acknowledged its existence in the space of religious freedom in Indonesia, such as: religion Parmalim (North Sumatra), Kaharingan (Central Kalimantan), Sunda Wiwitan (Bedouin, Banten), Naurus (Island Seram, Maluku) which combines Hindu and animist beliefs into their practices as well as many who follow the principles of Christian Protestant. In addition, there are also Sikhs in relatively small quantities ${ }^{30}$, But in fact more so that everything is not mentioned in this article.

If we refer to the second paragraph of Article 28E of the 1945 Constitution, affirmed that "Everyone has the right to freedom of belief believing, express thoughts and attitudes, according to his conscience ". The provision is reaffirmed by Article 29 paragraph 1 and 2, which states: "State based on belief in one God", and "State of Independence

30 Religious Affairs estimates that between 10,000 and 15,000 Sikhs who live in Medan and Jakarta. There are eight Sikh temple (Gurdwaras) located in North Sumatra. While in Jakarta there are two Sikh temple with an active congregation worship. 
ensuring each population to embrace religion and worship according to his religion and belief". If both provisions are freely interpreted, then the 1945 Constitution actually reflects the two principles on the right to freedom of religion, namely: First, the right to believe in a trust; and second, the right to express their reflections and attitudes in accordance with their conscience.

By looking at the various phenomena that have been raised regarding the case of "restrictions" on religious freedom that has been mentioned previously, the author dared to conclude that the constitutional guarantee against-the rights of religious freedom in the era of reform has not been implemented well. In fact, the condition is now "much worse" if you view the fact that the perpetrators of violence against religious freedom today is not only the country as a single actor, but also the community. ${ }^{31}$ Whereas the guarantee of religious freedom in Indonesia basically also have legal protection on an international scale through several ratification of human rights ever made by the Government of Indonesia. Guarantee of religious freedom is stated very clearly in:

a. Universal Declaration of Human Rights (UDHR), in particular Article 18 which states: "Everyone has the right to freedom of tought, conscience and religion; this right includes freedom to change his religion or belief and freedom either alone or in community with others and in public or private, to manifest his religion or belief of teaching, practice, worship and observance". ${ }^{32}$

31 The Author of "deliberately" did not spell out in more detail about the various concrete facts related to violence against religious freedom in the era of reform with a view to eliminating the elements outside the legal aspects. Besides, the Author also intends to maintain the objectivity of writing, so it needs to "prudence" to discuss the issue of religious freedom in Indonesia as an issue "very sensitive" in a constitutional perspective.

${ }^{32}$ Everyone has the right to freedom of thought, conscience and religion; this right includes freedom to change religion and belief, and freedom of religion or belief in teaching activities, worship, promotion and observance, either individually or jointly with others, in public or in private. 
The ratification of Universal Declaration of Human Rights (UDHR) adopted by the Government of Indonesia based on the Act Number 39 of 1999 on Human Rights, particularly Article 22, which concerns the guarantee of the right to freedom of religion.

Furthermore, Article 22 of the Act Number 39 of 1999 on Human Rights stipulates that: First, "Everyone is free to embrace their religion and to worship according to his religion and belief"; Second, "The state guarantees the freedom of every person to profess his own religion and to worship according to his religion and beliefs it.

b. The Act Number 12 of 2005 on RatificationInternational Covenant on Civil and Political Right (ICCPR) ${ }^{33}$.

Consequences to ratify International Covenant on Civil and Political Right (ICCPR), the Indonesian Government is bound to ensure:

1) right of everyone to freedom of thought, conscience and religion, and protection of these rights; ${ }^{34}$

2) the right to hold opinions without interference by other parties and the right to freedom of expression; ${ }^{35}$

3) equality of all people before the law and the rights of all persons equal protection of the law without discrimination ${ }^{36}$;

4) measures to protect the ethnic, religious or linguistic minorities which may exist in the State party (country involved signed international covenants intended). ${ }^{37}$

The above responsibilities very clearly reflected in Article 8 of the Act Number 39 of 1999 on Human Rights, which affirms "the protection, promotion, enforcement and fulfillment of human rights

\footnotetext{
${ }^{33}$ International Covenant on Civil and Political Rights

${ }^{34}$ Article 18 of the Act Number 12 of 2005

${ }^{35}$ Article 19 of the Act Number 12 of 2005

${ }^{36}$ Article 26 of the Act Number 12 of 2005

${ }^{37}$ Article 27 of the Act Number 12 of 2005
} 
is the responsibility of the state, especially the government". The fact that the case actually shows that the condition of religious freedom in Indonesia tend not reflect the values mentioned, well reflected by the Act Number 39 of 1999 on Human Rights and the CovenantCovenant ratified international as statutes derivatives.

In Article 5 Section Two of the Covenant on Civil and Political Right (ICCPR) explicitly states that :

1) None of the provisions in the Covenant shall be interpreted as giving the right to the State, group or individual to engage in activity or to perform any act aimed at the destruction of rights and freedoms recognized herein, or to restrict it more than those already set out in These covenants;

2) There should be no restriction upon or derogation of the right to basic human recognized or valid in participating countries covenants, according to law, conventions, regulations or custom on the pretext that the Covenant does not recognize such rights or that it recognizes but in a lesser degree.

If observed the provisions of Article above, it is found violating the provisions in question. Ironically the violations were actually done by the government itself and even society and pressure groups, with co-interfering religious faiths plural society.

On the other hand, the provisions of the International Covenant on Civil and Political Right (ICCPR) still found articles that do provide "respite" for the State that also ratified the Covenant are not to follow a few chapters liability has been determined, that Article 4, paragraph 1, which states that "in an emergency that threatens the life of the State and the situation has been declared officially, States Covenant may take measures that reduce (derogate) their obligations by covenants, as far as it is demanded by the emergency, provided that such measures should be in harmony with the obligations of others based international law and do not involve 
discrimination based on race, color, sex, language, religion or social origin solely".

The state should, in principle no way interfere in the internal affairs of a religion, especially in terms of determining the principal teachings, what is right and wrong, except in the case of occurrence desecration of a particular religion or doctrine and religious practice performed a religious community has led to a criminal act, including persecuting rights to freedom of religion and belief a person or entity, including that insult to other religions, murder, advocacy of mass murder, terrorist acts, resistance or armed rebellion against the state or the government, then the state is entitled and authorized to act decisively.

This paper is expected to become a new thesis. The charge correction and introspection in this paper even though there is mutual denial of the Constitutional Court's decision does not mean mutual annihilation against the truth of the concept of religious freedom in Indonesia. The antithesis of this article it is born of truth deny the thesis, and synthesis in the Constitutional Court's decision to accept the truth which he declined antithetical argument departs from the differences in perception between the two with each argument is different.

Back to the provisions of Article 2 paragraph (2) of Religious Blasphemy Prevention Act determine that authorities declare an organization / cult that violates the prohibition of abuse and / or blasphemyas an forbidden organizations $/$ streams $^{38}$ (bolding of Author) is to the President, having received consideration from the Minister of Religious Affairs, the Attorney General and the Minister of Home Affairs. ${ }^{39}$ To that end, established the Coordinating Agency for the

${ }^{38}$ Clause "forbidden organizations / streams" should be attributed to the interests of a state administrative order and not on the substance of truth in the viewpoint of religious material.

39 The existence of Article 2 (2) of the Act Prevention of blasphemy is a follow up of the provisions of Article 2 (1) of the Religious Blasphemy Prevention Act. Considerations regarding Article 2 Paragraph (1) shall also apply mutatis mutandis to Article 2 (2) of the Prevention of blasphemy. Article 2 (2) authorizes the President after being considered by the Minister of Religious Affairs, Minister / Attorney General and Minister of Home Affairs may dissolve the forbidden organizations / streams as a follow-up of Article 2 (1) of the Religious Blasphemy Prevention Act. 
Supervision of Community Trust (BAKOR PAKEM). While BAKOR PAKEM itself is actually the Trust Supervision Coordination Team established underAttorney General Decision No.: KEP004 / JA / 01/1994 dated January 15, 1994 on the Establishment of the Coordination Team Monitoring Mystical Beliefs in Society (PAKEM).

Letter of Recommendation from the PAKEM team then followed up with the publication the "Joint Decree (SKB) of Three Ministers" on June 9, 2008, which is a Joint Decree of the Minister of Religious Affairs, Attorney General and Minister of Home Affairs No.03 of 2008, No. KEP-033 / A / JA / 6/2008 and No. 199 of 2008 on Commemoration and Command to Adherents, Members and/or Board of Indonesian Ahmadiyya Jama'at (JAI) and Citizens, which essentially freeze the activities of the Ahmadiyya Qadiyani sect (Ahmadiyya), including prohibiting proselytizing by Ahmadis, in addition to prohibiting anarchist action against this group.

In response to the problems mentioned above, it is actually three things that must be protected related issue "Joint Decree (SKB) of Three Ministers" in the case of Indonesian Ahmadiyya Jama'at (JAI) when viewed from the aspect of criminal law, namely: First, the interests of individuals (individuele belangen); Secondly, the social interest/community (sociale belangen); and Third, the state's interest (staatsbelangen). Certainly not disappear from our memory, evacuation action to save the 283 member churches of the prophet cottage sect, the leader of the Pdt.Mangapin Sibuea that the teachings emphasize the impending doom that falls on November 10, 2003. The action taken by the Police as a state at the time it was the right because the gathering of Sibuea followers is considered to endanger the souls of the congregation, because of concern, they would commit suicide, as well as disturbing public security and public order ${ }^{40}$.

In its decision, the Constitutional Court judges that in fact religious accentuation freedom (freedom to act) is a fundamental right that can be limited (derogable right). The Court found the two provisions "permissible restriction" in

40 Yafet Rissi, Op.Cit., p.58 
exercising rights and freedom of religion which is a legal fact recognized by the parties, namely the Petitioners, the Government, House of Representatives (DPR), the Related Parties, Witnesses, and Experts, are contained in: ${ }^{41}$

a. Article 28J paragraph (2) of the 1945 Constitution which states:

"In carrying out their rights and freedoms, everyone shall be subject to restrictions established by Act (bold letters from the Author) with the sole purpose of securing due recognition and respect for the rights and freedoms of others and to meet the fair demands in accordance with considerations of morality, religious values, security and public order in a democratic society"

Similarly, the state is not entitled to intervene in the interpretation of the faith or trust someone not to interfere with the interpretation of a particular religion, but in the explanation I General Number 4 of the Religious Blasphemy Prevention Act, determined that "Since the purpose of fostering peace of religion here, then the Presidential Determination, first of all prevent them from happening abuses of religious teachings are regarded as principal teachings by the scholars of the religion concerned"

b. Article 18 paragraph (3) of the Act Number 12 of 2005 on Ratification International Covenant on Civil and Political Rights (International Covenant on Civil Rights and Political) stating "Freedom to manifest religion or beliefs may only be restricted by legal regulations (bold letters from the Author), and are necessary to protect public safety, order, health, or morals society, or the rights and fundamental freedoms of others" Meanwhile, Article 20 paragraph (3) of the same Act states "Any action that promotes hatred on the basis of nationality, race or religion which is the incitement to discrimination, hostility or violence should be prohibited by law" (bold letters from the Author)

41 The Decision of the Constitutional Court of the Republic of Indonesia Number 140/PUUVII/2009 on Review of Laws Number 1/PNPS/1965 on the Prevention of Abuse and / or Blasphemy against the 1945 Constitution, P.269 
Strengthening the two legal bases above, Michel Hager ${ }^{42}$ further confirms there are three legal functions (read: Act) as a means of development guardian, namely: First, the law as an ordering tool which means the law can create a political decision-making and dispute resolution.

The first function of the law, according to the Author is the opposite of one theoretical classification of $\mathrm{Mattei}^{43}$, which confirms that the legal system is generally applicable in developing countries is a legal system that is dominated by political intervention. The views of pluralism within the meaning of substantially the practice of enforcement of the Religious Blasphemy Prevention Act always using postulates E Pluribus Unum, that the recognition of religious diversity or community tend to avoid political action arbitrarily performed by a group - can be a political regime, interest groups, ethnicity, religion, etc. ${ }^{44}$

Second, the law as a tool of balance guard which means the law (read: Act) serves to maintain harmony between the public interest with the individual interests; Third, the law as a catalyst, which means the law (read: Act) serves to make easily the process of change.

2. Aspect of external freedom (forum externum).

External freedom (forum externum) is a person's freedom to express, communicate, or manifest spiritual existence he believes it to public and defend (italics of the Author) beliefs.

The religious believers which are included in the aspect of external freedom according to the Author, it is possible that they failed in obtaining the truth of the religious epistemology they believed in, though his ontological beliefs cement the absolute truth of his religion. The sensitivity

${ }^{42}$ Yanis Maladi, (2008), National Land Registration Law and Life Society, Yogyakarta: Crown Word, p.49.

${ }^{43}$ U.Mattei, (1997), Three Patterns of Law: Taxonomy and Change in the World's Legal System, The American Journal of Comparative Law, p.45.

${ }^{44}$ Heru Nugroho, "SARA Who Framed Pluralism", KOMPAS, Saturday, March 15, 1997, p.5 
of religious people who belong to the aspect of external freedom only arises when they come across religious formal deviations, but remain blind to social and humanitarian abuses ${ }^{45}$.

In the context mentioned above, the Religious Blasphemy Prevention Act does not limiting one's beliefs (forum internum) as adherents one of religion which tends to accentuate his religion truth claims which redundant, which certainly underlies every his behavior. But the Religious Blasphemy Prevention Act just limiting the thought statement and attitude appropriate to his conscience in public (forum externum) assessed deviate from the principal teachings of a religion followed in Indonesia, issued a feeling or does something which is fundamentally hostility, abuse or desecration of a religion followed in Indonesia.

Continuing the understanding of the religious believers that belong to the aspect of external freedom (forum externum), that the religious believers of the textual stream, literalist and scripturalists feared would give birth to the Indonesian people are hypocritical, which is more focused on doctrinal truths and dogmatic that tend to be exclusive, primodialistik even compulsive, namely certainty unbearable to realize a desire or lust (in the name of religion) by using any means, so in diametrical occurs collision or conflict.

At this point, the state has a role to bridge or accommodate any conflicts because of religious differences. To that end, the demands of the state's role as it can only be realized if the Government really inherent in the society, so that any resulting policy always represent the community. For that, it needs an adequate political infrastructure also is the role of the state through the Constitutional Court as a facilitator, motivator and stabilizer forces that exist in religious institutions. At the time the Government had difficulty in realizing the law enforcement system is right and just, because the law itself may favor the dominant forces that may not

45 Totok Ariyanto, "Ending Hypocrisy Religious Education", Kompas, Saturday, August 10, 2002, p.5 
in favor of truth and justice, that's when the Constitutional Court is expected to give birth to substantive justice through its decisions.

On the other hand, the Author emphasizes optimism, when the conflict because of religious pluralism in Indonesia is packaged in a democratic political system there will be a diametric change from conditions of conflict into the public discussion. Because basically, the debate will produce an agreement (consensus). Because the agreement is the way out toward the dialectic between debate and agreement in Indonesian realize that although the plural but not eliminate major elements as a democratic society and very upholds tolerance of against differences formed by pluralism itself.

\section{CONCLUSIONS AND RECOMMENDATIONS}

\section{Conclusion}

Moving away from the main problem that has been raised, this paper comes to the following conclusion :

a. In essence, the Religious Blasphemy Prevention Act only regulates the abuse and blasphemy of religion, and ensure that the freedom of religion in Indonesia is not abused blasphemy against inter-religious who feared the potential to cause anarchy, so that the Religious Blasphemy Prevention Act become one of the forms of state protection to ensure the creation of harmony and tolerance of religion and belief in realizing public order for the plural Indonesian society.

b. In general, the Government respects religious freedom, but in fact, restrictions on freedom of religion and belief continue to have problems and challenges of the Government and even the public, especially on religion and belief are not recognized, and the doctrines and religious practices and beliefs that are considered contrary to the values of socio-cultural who live in the community, and law or the rules imposed by the state is exception of respect for religious freedom and belief in Indonesia. 


\section{Recommendations}

In order to realize the democratic Indonesian society and uphold tolerance toward religious pluralism and recognize pluralism and freedom of religion, it is recommended :

a. It is recommended that The Religious Blasphemy Prevention Act be immediately revised in a new Act, considering that material, the content or substance of legal norms formulation contains inconsistencies and indicated discriminatory. Among the provisions of the legal norms contained in the Explanation, which should be regulated in the provisions of Article, as well as the addition of a clause in the Religious Blasphemy Prevention Act is not uncommon in techniques of legislative drafting. Although formally, the Religious Blasphemy Prevention Act still has validity common binding by the Transitional Provisions Article I of the 1945 Constitution.

b. It is suggested that the Government policy that produced consistent in placing political infrastructure that recognizes pluralism and religious freedom by involving people who are granted the right to engage in dialogue Inter-religious which is based on equality, openness, honesty and sincerity between the two parties to engage in dialogue that is expected to give birth to the same understanding that religious pluralism in addition to potentially create a conflict but it can also be a force in realizing democratic society and upholds tolerance of differences formed by pluralism itself.

\section{Bibliography}

\section{Books, Journals and Newspapers}

Ahmad Gaus AF, 2008. Religious Freedom and Rights of Minorities in Indonesia, Jakarta: Paper presented in the workshop on "Promotion of Religious Freedom and Minority Rights for Social Integration," implemented by the Center for the Study of Religion and Culture (CSRC ) - UIN Syarif Hidayatullah, Jakarta in collaboration with Cordaid Netherlands, Puncak, West Java, 5-7 November 2008 
Charles, W.Anderson, et.al., (1967). Issues of Political Development, Englewood Cliffs, NJ: Prentice-Hall.

Eka, Darmaputera, (1997), Pancasila: Identity and Modernity - Review of Ethical and Cultural Rights, Molds VI, Jakarta: BPK Gunung Mulia

Franz Magnis, Suseno, (2006), Scramble the Nation's Soul, Jakarta: Compass Book Publishers

Gavin, W.Jones, (1978), The religions in Indonesia: History and Development, Jakarta: Prisma.

Hildred, Geertz, (1963), "Indonesia Cultures and Communities", in Ruth. T.McVey, ed., Indonesia, Berkeley and Los Angeles: University of California Press.

JH Boeke, (1953), Economics and Economic Policy of Dual Societies as Exemplified by Indonesia, Harleem: HD Tjeenk Willink.

Jeanne, S. Mintz, (1965), Mohammed, Marx and Marhaen. New York, Washington, London: Frederick A. Praeger.

Heru Nugroho, Kompas Daily, "SARA Framed Pluralism", Saturday, March 15, 1997.

Kompas Daily, "Religious Freedom Agenda", Friday, October 15, 2004.

Totok Ariyanto, Kompas Daily, "Ending Hypocrisy Religious Education", August 10th, 2002.

Mahfud MD, (1998), Political Law in Indonesia, Jakarta: LP3ES.

Mattei, U., (1997), Three Patterns of Law: Taxonomy and Change in the World's Legal System, the American Journal of Comparative Law.

Indonesian Constitutional Court Decision Number 140 / PUU-VII / 2009 on Review of Laws No. 1 / PNPS / 1965 on Prevention of Abuse and / or Blasphemy to the Religion against the Constitution of the Republic of Indonesia Year 1945

Rahmat Subagyo, (1973), Faith-Spirituality, Spiritual, Psychological and Religious, Jakarta: Spectrum.

Reuven Kahane, (1973), "The Problem of Political Legitimacy in an antagonistic Society: The Indonesian Case". Sage Research Papers in the Social Sciences, 
Vol 1, Series No. 90-005, Studied in Comparative Modernization Series, Beverly Hills and London: Sage Publications.

Siti Aminah and Parulian Uli Sihombing, (2011), Understanding the Different Opinions (Dissenting Opinion) the Decision of the Review of Laws of the Religious Blasphemy Prevention Act, First Edition, Jakarta: The Indonesian Legal Resource Center (ILRC).

Weda, Made Darma, (1996). Criminology. Jakarta: King Grafindo Persada.

Japheth, Rissi, (2004). "Quo Vadis Draft Law on Religious Harmony?", Journal of Interdisciplinary Development Studies, Volume XVI, No. 1, April 2004, Salatiga: Graduate UKSW

Yanis, Maladi, 2008. The National Land Registration Law and Public Life. Yogyakarta: Crown said.

\section{Legislations}

Indonesia, the 1945 Constitution of the Republic of Indonesia

Indonesia, Act No. 12 of 2005 on Ratification International Covenant on Civil and Political Right (ICCPR)

Indonesia, the Act Number 39 of 1999 on Human Rights

Indonesia, the Act Number 1 / PNPS / 1965 on Prevention of Abuse and/or Blasphemy to the Religion (Gazette of the Republic of Indonesia Year 1965 Number 3, Supplement to the State Gazette of the Republic of Indonesia Number 2726) juncto the Act Number 5 of 1969 on the Statement of Presidential Decisions Variety and Presidential Regulation as Act (Gazette of the Republic of Indonesia Year 1969 Number 36, Supplement to the State Gazette of the Republic of Indonesia Number 2900)

\section{Website}

Vivanews.com, attack on Ahmadiyah, Komnas: Case Cikeusik Gross Human Rights Violations, http: // nasional.vivanews.com / news / read / 203 334Komnas-ham-sby-not-enough-say-sorry, Accessed February 7, 2011 